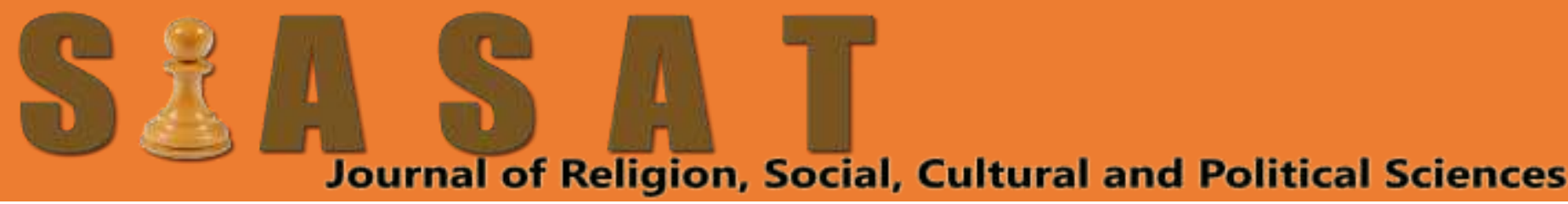

\title{
Pandemics in the past Eight Centuries: A Sociological Appraisal
}

\author{
Mohammad Taghi Sheykhi', Muhammad Ridwan ${ }^{2}$ \\ ${ }^{1}$ Professor Emeritus of Sociology, Alzahra University, Tehran, Iran \\ ${ }^{2}$ Universitas Islam Negeri Sumatera Utara, Indonesia \\ mtshykhi@alzahra.ac.ir,bukharyahmedal@gmail.com
}

\section{Abstract}

The present article intends to reflect the appearance of different pandemics in different periods from sociological point of view. Earlier pandemics used to appear without being able to control them; at the historical times without medications, hospitals, motor vehicles, without communications etc. Millions of people died because of spreading unknown diseases such as flu, cholera, black death, plague and the like. Estimates show that the first 15 events killed over 85 million people. Plague in Italy during some years in the 17th century perished many people vs the least of facilities within reach. Similarly, great plague in Spain in mid 17 th century took the lives of a large number of people. Great plague of London also in the second half of the 17th century killed more than 100,000 of citizens. Such events not only directly killed older household members, but created bad lives and deprivation for the younger remaining members in such households. Many of such children had to resort to orphanages. Cholera outbreak also appeared in early 19th century in India, Russia and Africa leaving behind a great number of deaths. The flu pandemic at the end of 19th century killed many people. Many countries came to know more on influenza since then. The outbreak of Coronavirus in 2020 is the worst very widespread and global affecting and infecting many people in all corners of the world. Coronavirus pandemic is wide spreading without being prevented. Despite all the existing facilities, it is killing more than the earlier pandemics in terms of time and space. As education and understanding of people are currently higher than before, they highly feel distressed and disordered.

\section{Introduction}

Different events of pandemics since early 14 century can be sociologically traced and evaluated. Black Death starting in 1331 and ending in 1353 is known as one of those. It happened at a time when the total population of Europe was not as high. As recorded a death toll of between 75-200 million is estimated. As investigated, the event of Black Death in 1330s was followed by other natural disasters such as the widespread famine starting in 1331 and weather conditions which contributed to the severity of the Black Death (Baten et al. 2005). Due to climate change in Asia, many rodents fled the dried-out grasslands to more populated land which caused spreading the disease (Tignor et al. 2014). The pandemic of Black Death transmitted by rodents and via fleas from West Asia, Central Asia, and North India to Europe diminishing primarily the population of Europe (Https). As found out, rat was the main vehicle of transmission of the disease (Yersin, 1894). The spread of the disease was more observed in areas with higher poverty. The disease of Black 
Death highly ravaged cities and in particular children. Black Death widely killed the vulnerable people by lice, unsanitary drinking water, by poor sanitation and the like.

However, during the Black Death, the only remedy recommended was the idea of quarantine; if applied, people were protected against the disease and the spread of that. Transmission of Black Death was found within parts of Asia too. Researchers show a large number of Black Deaths in India and China.

\section{Research Methods}

Methodology used in the present article is of qualitative type. In that, various paradigms have been used to find out about the facts regarding pandemics during the history. Qualitative research usually studies people, events or areas in their natural settings. In finding facts for the research, the researcher engaged in careful data collection and thoughtful analysis of what was relevant. In the documentary research applied for the present research, printed and written materials were widely regarded. The research was performed as a qualitative library-type in which the researcher had to refer to the relevant and related sources. In the current research, various documents were thoroughly investigated, and the needful inferences were made. The data fed by the investigator in the present article is hopefully reliable. Though literature on pandemics is very limited, yet the author tried to investigate many different resources in order to elicit the necessary information to build up the text.

\section{Results and Discussion}

\subsection{Italian Plague 1623-1632}

Though the plague pandemic is referred to the year 1623, but some others relate the starting of that, to the year 1629 , lasting to the year 1631 . The problem created a turmoil, especially in Italy. The spread of the disease was so vast that it claimed almost one million lives, or about $25 \%$ of the population (Hays, 2005). Plague of Italy highly contributed to the decline of Italy's economy as compared with other Western European economies (Alfani, 2013). German and French troops played an important part in transmission of the disease to the city of Mantua in 1629. As a result of the outbreak, Milan suffered the most with 60,000 fatalities. Likewise, the city of Venice was badly hit by the Plague with 46,000 deaths with a population of 140,000. The whole event had a serious impact on economic cycle and social relationships of the region. Commercial and political power of Italy experienced a serious hit and downfall. The outbreak also shattered the religious city of Bologna with an estimated death toll of 15,000. Due to shortage of medications and other facilities many people were easily sacrificed.

Sociologically speaking, Plague in Italy had its own social and economic effects. Because of the pandemic at that time, many people used to abandon their friends and families, fled cities, and locked themselves in some secure places. Funeral rites stopped and many professions ceased too. So, many people used to fight the plague with prayer in Italy. Because of the death of many clergies and failure of prayer to prevent sickness and death in Italy, faith in religion decreased after the Plague. Similarly, economy experienced extreme inflation because of stoppage in trade and commerce (Retrieved, 2020). 
Table 1. Population, Death Toll and Percentage of Population Lost in Selected Cities, Italy, 1630

\begin{tabular}{|c|c|c|c|}
\hline City & $\begin{array}{c}\text { Population in } \\
\mathbf{1 6 3 0}\end{array}$ & $\begin{array}{c}\text { Death Toll by } \\
\mathbf{1 6 3 1}\end{array}$ & $\begin{array}{c}\text { Percentage of } \\
\text { Population Lost }\end{array}$ \\
\hline Verona & 54.000 & 33.000 & $61 \%$ \\
\hline Milan & 130.000 & 6.000 & $46 \%$ \\
\hline Venice & 140.000 & 46.000 & $33 \%$ \\
\hline Bologna & 62.000 & 15.000 & $24 \%$ \\
\hline Florence & 76.000 & 9.000 & $12 \%$ \\
\hline
\end{tabular}

Source: Alfani, G. (2013). Plague in Seventeenth-century Europe and the Decline of Italy: An Epidemiological Hypothesis, European Review of Economic History

\subsection{Great Plague of Seville 1647-1652}

It is a massive outbreak of a disease in Spain killing about a quarter of the people of Serville. Over all, Spain is thought to have lost 500,000 people. When the total population of Spain was about 10,000,000, approximately 500 thousand, or nearly $5 \%$ were killed by the disease. Spain has experienced different and repeated Plagues. Between 1676 and 1685 another outbreak ravaged the country through different waves. It hardly hit different areas of Valencia and Andalucia.

Plague in Spain affected normal births, deaths and emigration. Food shortages and rapidly inflating prices were a fact of life during the crisis in Spain. Wheat, oats, hay and consequently livestocks were in short supply. Their scarcity resulted in malnutrition, which eventually weakened the immunity system (Bennet, 2006). The modern human Plague is known as having a mortality rate of 30 to 75 percent symptoms including fever of 38-41 C (101-105 F), headaches, painful aching joints, nausea, vomiting and a general feeling of malaise (Totaro, 2005).

\subsection{Great Plague of London 1665-1666}

The great tragedy claimed roughly $15 \%$ of the population of London. Though 68,596 deaths were recorded in the city of London, the true number was probably more than 100,000. Not only London, other parts of the country also suffered. The first cases of the disease emerged in the Spring of 1665 in a Parish outside of London. The death toll began to increase in the hot Summer of that year. Increasing deaths were transported in horsecarts from different parts of London to the cemetery. The rate of death peaked in the September when 7,165 of London people lost their lives in one week. Rats played a good part in carrying and causing the Plague. It more happened in the poor areas of the city filled with more rubbish and waste (Defoe, 1665). In those days there were no newspapers or radios. People only depended on preachers. Many people such as maid servants or male servants were stressful asking if their masters would take them to other parts of the country or not. They were worried about such matters.

The great Plague of London was the last major epidemic in England in the 17th century. The event killed an estimated 100,000 people__ a quarter of London's population in 18 months (Retrieved, 2015). The Plague was initially caused by the Yersinia pestis bacterium which is usually transmitted through the bite of an infected rat flea (Retrieved, 2013).

Plague of London more and widely impacted the poor who could not leave the city. After the Plague, the structure of the city changed _ streets were widened, many gracious buildings were constructed. The rebuilding project took about 10 years (Hart, 2002). After the September 1666, trade and business recommenced in London. This was 
followed by the return of the citizens previously left the city. Overall, a lot of change appeared in London after the Plague ceased.

\subsection{The Great Plague of Marseille 1720-1722}

The disease as reported, originated in Asia, and killed a total number of 100,000 people in Marseille and around it. The disease took the lives of 1000 people everyday. It perished a huge number of people in South of France. It was a disaster with various social and economic dimensions. The central government arranged a council of Health in Paris to supervise all aspects of the crisis in the southern part of France during the Plague. Langeron as the Commander in Chief of Marseille, among his attempts to pacify the crisis organized religious processions. He also executed martial law in the region to police and administer the city.

As explored, Marseille has been exposed to different epidemics for two millennia including Plague, Cholera, Yellow Fever etc. This situation has given the people of Marseille a better power to stand and fight the epidemics.

The knowledge of two thousand years worth of epidemics in the region is based on sociological and anthropological studies (Tzortzis, 2016). The city of Marseille equipped itself for centuries with preventive measures against infectious disease control and other epidemics which were taken as an example by other cities in Europe. However Typhus and Smallpox were added in 1926. The first Lazaret of Marseille was established in 1526 on the Island of Pomegues to control ships coming in from Muslim countries into France from 1622 (Mafart, 1998). Marssille's inhabitants exposing to two thousand years to the epidemics that crossed the Mediterranean Basin, obtained expertise in the diagnosis, treatment and prevention of these epidemics.

\subsection{First Cholera Pandemic 1816-1826}

The first Cholera Pandemic began near Calcutta, India and spread South and Southeast Asia, the region of the Middle East, eastern Africa and the Mediterranean coast (Hays, 2005). The disease gradually reached Bombay on the West coast and around Ganges River. The disease soon went to beyond India to Siam, Parts of Russia, Zanzibar and Mauritius. The transmission of the disease ended in 1824. The Hindu Pilgrims had a good impact on spreading the disease all over India. Similarly, the British troops transmitted Cholera to Afghanistan and Nepal. The merchant ships also carried the infected people to parts of Africa, North China and Japan. The death toll for India is estimated 1.24 million per year, and the total death number is estimated about 8,750,000 during the Cholera Pandemic.

Because of the Cholera Pandemic, a sort of Anti-Asian Sentiment was moulded with special reference to Indian people and culture. Outsiders blame and criticize India for its Hindu pilgrimages and the hygiene following the initial outbreak (Retrieved, 2020).

Between 1816 and 1923, the first six pandemics occurred consecutively over time. Increasing migration, commerce and pilgrimage played a good part in its transmission. In late 1879-1883, major attempts were made towards the treatment of the disease. Access to the first Cholera Vaccine and identification of the bacterium were important steps towards its stoppage.

Different Cholera Pandemics are as follows:

First, 1817-1824 in Bengal, India.

Second, 1829-1837 in Hungary (about 100,000 deaths).

Third, 1846-1860 affected Russia with over one million deaths.

Fourth, 1863-1875 began in the Ganges Delta of Bengal region. 
Fifth, 1881-1896 killing 250,000 people in Europe, and at least 50,000 in Americas.

Sixth, 1899-1923 occurred in Western Europe with about 500,000 deaths.

Seventh, 1961-1975 in Indonesia, and East Pakistan (Bangladesh).

\subsection{Second Cholera Pandemic 1829-1851}

The Second Cholera Pandemic also originated in India along the Ganges River delta. Cholera caused more deaths than any other epidemic disease in the 19th century. It was transmitted through contaminated river waters and contaminated foods. The first Cholera Pandemic (1817-24) began near Calcutta, and spread through Southeast Asia to the Middle East, eastern Africa, and the Mediterranean coast. Hundreds of thousands of people died because of Cholera outbreak. It spread almost all over Asia. The second Cholera Pandemic also diffused from Russia to the rest of Europe killing hundreds of thousands of people. During the second Cholera Pandemic, different beliefs were there. In France, doctors believed Cholera was associated with the poverty of certain communities, or the poverty of environment. In the United States it was believed that the disease had been carried by the migrants from the British ports (Hays, 2005).

\subsection{Russia Cholera Pandemic 1852-1860}

The third Cholera Outbreak is associated with years 1852 and 1860. More than one million people died because of this disease (Frerichs, 2018). The disease also had high fatalities in Africa, Asia, Europe and North America too. In great Britain some 23,000 people died by the disease. The extension of the disease was so wide. The Cholera extension killed over 15,000 people in Mecca in 1846.

Snow identified the source of 1854 Cholera Disease on contaminated water, the water pumps on the main streets in London. Snow's study is found to be a major discovery in epidemiology including public health and geography. The discovery by Snow contributed to the construction of improved sanitation facilities in mid-19th century (Eyeler, 2001).

\subsection{Global Flu Pandemic 1889-1890}

The Flu Pandemic of 1889-1890 also known as the "Asiatic Flu" or "Russian Flu" was a severe disease killing more than one million people worldwide. Many researchers have widely tried for years to find out the subtypes of Influenza as responsible for 18891890 epidemics. Eventually and after attempts, they came to identify H3N8 subtype was more likely the cause for the 1889-1890 Pandemic (Dowdle, 1999).

Most Americans learnt of influenza in early December 1889. After the top European leaders fell sick because of the disease, Americans were updated of the situation on a daily basis. Then they came to take it more seriously. However, the first case of influenza was reported in US on December 1918, followed by a gradual increase. Because of the immediate spread of the flu, mask wearing as a rule was practiced in 1918.

\subsection{Sixth Cholera Pandemic 1899-1923}

This Pandemic began in India, and soon spread to the Middle East, Russia, Eastern Europe and North Africa. The outbreak killed 800,000 people in India (Retrieved, 2019). The last Cholera outbreak spread to Europe through Punjab, Afghanistan, Persia and Southern Russia (Dasgupta, 2015). However, the most important reason for transmission of Cholera are known as commerce, migration, and pilgrimage. Also, the major breakthroughs towards the treatment of Cholera developed through immunization by Pasteur, creation of the first Cholera vaccine, improving quality of drinking water and the 
like (Handa, 2016). Unlike tuberculosis, Cholera is a disease which generally entirely affects the lower classes living in filth and poverty.

Origins of Cholera indicate that every year 3 to 5 million people around the world are affected by the disease, and between 100-120 thousand people die from the infectious disease according to the estimates of WHO. The disease has been there since the times of Lord Buddha. It still more or less happens in India, but medications are there to treat it.

\subsection{Encephalitis Lethargica 1915-1926}

The disease attacks the brain which leaves the patient in a statue-like condition, usually motionless and speechless (Dale, 2004). Between 1915-1926, the Epidemic of Encephalitis Lethargica diffused around the world affecting about 5 million people, and one third of whom died in different stages.

Such patients were conscious and aware, but not fully aware. They used to sit speechless and motionless all the day, totally in short of impetus, energy, motive and appetite. They were indifferent toward what went on around them. They also did not feel life as much. They were somehow passive (Sacks, 1973).

In winter 1916-1917, a new illness suddenly emerged in Vienna and other cities, and soon diffused worldwide over the later three years. During the 10 years followed, almost the lives of 5 million people were taken. This pandemic disappeared in 1927 (Sacks, 1990). The disease is progressive, and the damage of which is similar to Parkinson's disease. The treatment of Lethargica is known to be symptomatic (Encephalitis Lethargic, 2018).

\subsection{Spanish Flu 1918-1920}

The Spanish Flu Pandemic of 1918 infected about 500 million people of the world, nearly one-third of erstwhile planet's population taking the lives of 20 to 50 million people including 675,000 people in America. Though the Flu was first observed in Europe and US, and it soon spread in Asia and the worldwide. Citizens were ordered to wear masks, and schools, businesses and theaters were shuttered. Influenza, or Flu is a kind of virus that mainly attacks the respiratory system.

\subsection{Asian Flu 1957-1958}

The Flu originated in Singapore, and then to Hong Kong and the coastal cities in America in 1957. The pandemic that is also called (H2N2) killed 1.1 million people worldwide and 116,000 people in the United States. The pandemic also affected Taiwan, India, England and the Wales etc. (Jackson, 2009). Asian Influenza caused a respiratory illness, a dry cough, sore throat, and difficulty in breathing. The Flu usually results in a sort of high fever and body aches or chills. Losing weight and appetite are also followed, and the recovery of which is complicated, and mostly leads to seizures and death.

\subsection{Hong Kong Flu 1968-1969}

The Hong Kong Flu also known as the Flu Pandemic of 1968 whose outbreak killed one to four million people by estimate throughout the world, the disease was caused by an H3N2 influenza A virus; a descendent from H2N2 through an anti-genetic shift (Jester, 2020). By September 1968, the Flu had reached India, the Philippines, Northern Australia and Europe. It also entered California in the same month, but not spread all over US. The Hong Kong Flu penetrated Japan, Africa and South America by 1969. The disease was spreading until its Vaccine became available four months after it had started (Bojan, 2020). 


\subsection{H1N1 Pandemic 2009-2010}

In the Spring 2009, a novel disease or influenza (H1N1) virus emerged. It soon diffused around the United States, followed by other parts of the world. The disease contributed to better understanding influenza and prevent the disease. The Flu or H1N1 culminated in 203,000 deaths. However, enough vaccines were made and circulated throughout USA, followed by vaccination for all the people. But, many countries that were not affected, were not vaccinated. The Swine Flu was rapidly controlled in countries where it was spread (Novel Swine-Origin Influenza, 2009). The World Health Organization used the term "(H1N1) 2009 Pandemic", when the event is referred to (Retrieved, 2020).

\subsection{Coronavirus 2020}

The Virus is changing many social norms and values almost all over the world. Many countries are surprisingly facing the new deadly crisis. Coronavirus has caused sudden and unexpected deaths for many of different age groups leaving behind increasing social, economic, psychological and family problems. The phenomenon has led to shortages of medical staff and equipment. The crisis of Corononavirus has contributed to the lack of beds in hospitals for regular patients. Therefore, the ordinary patients are facing closed doors. However, Coronavirus-hit is more difficult for women than men. Men, may usually marry even in their old age, but women do not often have that chance.

\section{Conclusion}

There have been different approaches towards various pandemics in different ages. The first event killed about 75,000,000 people in the age when no facilities were there as available in modern time. Great Plagues destroyed millions of people in Europe, Asia and other parts of the world. Later, cholera pandemic claimed millions of lives in Asia, Russia and other parts of the world. Pandemics were followed by flu in Spain and Asia, spreading widely to various corners of the world; killing millions of people. In modern era, Coronavirus is widely attacking each and every class of people worldwide. But, attempts are being made to produce its vaccine in many countries. Similarly, means of communications have facilitated it to know about new cases and deaths per day. Though people are lockdown indoors, food and educational means are accessible electronically. However, about two-thirds of affected people are treated to get up, to continue life normally. In modern era, there are doctors and nurses enough in each country to hospitalize and treat the patients. On the contrary, there were not such facilities to control the Plague and Cholera patients before. Modern electronic devices are playing a vital role in identifying and treating the disease in 2020. Yet, Coronavirus is paralyzing tourism, productions, industries, many trades, economies of all sorts etc. Though countries used to have enough hospital beds before Coronavirus, yet they feel a shortage of hospital beds more due to the influx of Corona patients. However, the appraisal of pandemics gives us a good sociological knowledge of the past pandemic events.

\section{References}

Alfani, G. (2013). Plague in Seventeenth-Century Europe and the Decline of Italy: An Epidemiological Hypothesis: European Review of Economic History. vard Retrieved 2020, Decameron Web.

Anti-Asian Racism in the 1718 Cholera Pandemic, Retrieved 2020. 
Backgrounder: Plague, AVMA: Public Health. American Veterinary Medical Association, Retrieved September 2013.

Baten, Joerg. et al. (2005). The Biological Standard of Living in Europe during the Last Two Millennia. European Review of Economic History.

Bennett, J.M. et al. (2006). Medieval Europe: Short History, New York: McGraw-Hill.

Boja, P. (2020). Forgotten Pandemic Offers Contract to Today's Coronavirus Lockdowns, Wall Street Journal.

Cholera's Seven Pandemics, Canadian Broadcasting Corporation, Retrieved 2019.

Dasgupta, R., Time Trends of Cholera in India: An Overview, Retrieved 2015.

Dale, R.C., et al. (2004). Encephalitis Lethargica Syndrome: 20 New Cases and Evidence of Basal Ganglia Autoimmunity, Retrieved 2004.

Defoe, D. (1665). Online Version.

Dowdle, W.R. (1999). Influenza A Virus Recycling Revisited. Bulletin of the World Health Organization: Geneva

Eyeler, William. (2001). The Changing Assessments of John Snow's and WilliamFarr's Cholera Studies.

Encephalitis Lethargica Information (2018). National Institute of Neurological Disorders and Stroke.

Frerichs, R.R. Asiatic Cholera Pandemic During the Life of John Snow., Retrieved 2018.

Handa, S. (2016).Cholera Background, Med Scape, Retrieved 2016.

Hart, V. (2002). Rebuilding Ancient Wonders, Yale University Press.

Hays, J. N. (2005). Epidemics and Pandemics Their Impacts on Human History, Santa Barbara, California.

Jackson, C. (2009). History Lessons: The Asian Flu Pandemic, British Journal of General Practice, 59(565): 622-623.

Jester, B. J. et al. (2020). Fifty Years of Influenza A (H3N2) Following the Pandemic of 1968. American Journal of Public Health.

Mafart, B., et al. (1998). Historie du Concept de Quarentaine, Google Scholar.

Novel Swine-origin Influenza, A (H1N1) Virus Investigation Team.

Sacks, Oliver. (1973). Awakenings, New York: Harper Perennial.

Standardization of Terminology of the Pandemic A (H1N1) Virus, World Health Organization (WHO), Retrieved 2020.

Totaro, R. (2005). Suffering in Paradise: The Bubonic Plague in English Literature from More to Milton, Pittsburgh: Duquesne University Press.

The Great Plague of London (1665). Contagion, Historical Views of Diseases and Epidemics, Harvard University, Retrieved March 2015.

Tignor et al. (2014). Http://www.cdc.gov/plague/maps/index.html.

Tzortzis, S. et al. (2016). Characterization of the Funeral Groups Association with Plague Epidemics. Google Scholar.

Yersin, A. (1894). La Peste Buboniqu a Hong-Kong. Annales l' Inistitut Pasteur: Journal de Microbiologie. 